\title{
Stoneware Ceramic Synthesis with Iron Sand as a Filler Material
}

\author{
I Komang Wahyu Surya Permana1, Ida Bagus Alit Paramarta', Arifin Siagian², Made Sumadiyasa1 (i) \\ ${ }^{1}$ Department of Physics, Faculty of Mathematics and Natural Sciences, Udayana University, Badung, Indonesia \\ ${ }^{2}$ Technical Implementation Unit of the Laboratory of the Agency for the Assessment and Application of Technology, Center for \\ Creative Ceramics Industry Technology, Bali, Indonesia \\ Email: sumadiyasa@unud.ac.id
}

How to cite this paper: Permana, IK.W.S., Paramarta, I.B.A., Siagian, A. and Sumadiyasa, M. (2019) Stoneware Ceramic Synthesis with Iron Sand as a Filler Material. Journal of Materials Science and Chemical Engineering, 7, 42-51.

https://doi.org/10.4236/msce.2019.78006

Received: July 9, 2019

Accepted: August 13, 2019

Published: August 16, 2019

Copyright (c) 2019 by author(s) and Scientific Research Publishing Inc. This work is licensed under the Creative Commons Attribution-NonCommercial International License (CC BY-NC 4.0). http://creativecommons.org/licenses/by-nc/4.0/

\begin{abstract}
In an effort to explore the use of natural resources, stoneware ceramics have been made using iron sand as a filler to replace quartz Kalimantan. The results showed that iron sand can be well used in making stoneware ceramics. This is shown by the measurement of water absorption which is less than $5 \%$ and has compressive strength slightly smaller compared to stoneware ceramics made with quartz as a filler.
\end{abstract}

\section{Keywords}

Stoneware Ceramics, Iron Sand, Quartz, Pressure Strength, Water Absorption

\section{Introduction}

In general, the ceramics body can be made by mixing several materials: first is filling material i.e. quartz mineral $\left(\mathrm{SiO}_{2}\right)$, which can be quartz, chalcedony, dymite, cristobalie, opal, lechatelierite, coesite and stishovite [1] [2]. The filler material is resistant to acids and strong bases, responsible for the strength of the ceramics body both before and after combustion. Second, it is binding materials from clay minerals such as kaolinite, ballclay, talk and bentonite [3]. If the clay is added enough water, the clay becomes sticky and plastically, after drying the plasticity disappears but its shape remains unchanged. Third, smelter material is a material containing alkali metal. Smelter materials include feldspar, limestone, dolomite, but the most widely used feldspar. Potassium and barium feldspar compounds have a monoclinic crystal structure, while sodium and calcium feldspar has a triclinic crystal structure [4].

The minerals of quartz which are often used as fillers in the manufacture of ceramics are generally disclosed in the formula $\mathrm{WZ}_{4} \mathrm{O}_{8}$ where $\mathrm{W}$ is a metal $\mathrm{Na}$, 
$\mathrm{K}, \mathrm{Ca}$ or $\mathrm{Ba}$, and $\mathrm{Z}$ is a metal $\mathrm{Si}$ or $\mathrm{Al}$. The ratio of $\mathrm{Si}$ and $\mathrm{Al}$ varies between 3:1 1:1. Quartz has a melting point of $1715^{\circ} \mathrm{C}$, while feldspar that is widely used as filling material has the melting point at a temperature of $1250^{\circ} \mathrm{C}[5]$.

The characteristics of the body of the ceramics stoneware vary, generally ceramic craftsmen choose a body mass of raw materials that has the physical properties that are a plastically so easily formed (especially in the use of swivel techniques), allowing it to be formed in large sizes, having dry shrinkage not more than $5 \%$, there is no tendency to curve, crack and break during drying, post-burn with burn shrinkage no more than $6 \%$ and the water absorption between $1 \%$ to $5 \%[6]$.

In the previous study, stoneware ceramics have been made using Belitung quartz as a filler [7]. The use of quartz Belitung in the process of making those stoneware ceramics is to enhance quality, i.e. reduce dry shrinkage, reduce cracks in drying, reduces its burn shrinkage. From this study, it was found that its water absorption decreases with increasing temperature of combustion. At combustion temperatures of $1200^{\circ} \mathrm{C}$ for 24 hours stoneware ceramics with the water absorption of $5.5 \% \pm 0.1 \%$ was obtained.

In an effort to reduce water absorption and use of local natural resources, in this study stoneware ceramics were made by using iron sand as a filling material to replacing Belitung quartz. Iron sand is much found on the coast of Tegal Lenga Singaraja-Bali.

\section{Experiment}

\subsection{Synthesis}

The material used in this study is the same as that used in the previous study [7], except quartz Belitung was replaced with iron sand as shown in Table 1. The iron sand used was taken from the beach of Tegal Lenga Singaraja (Singaraja, one of the provinces in Bali), after sieving with a sieve measuring $1 \mathrm{~mm} 2$ the fine black sand was obtained as shown in Figure 1. The XRD characterization results show that the sand contains $74 \%$ Iron iron(III) titanium aluminium magnesium chromium vanadium (III) manganese silicon oxide

$\left(\left(\mathrm{Fe}_{4.42} \mathrm{Fe}_{5.245} \mathrm{Ti}_{4.72} \mathrm{Al}_{0.7} \mathrm{Mg}_{0.4} \mathrm{Cr}_{0.3} \mathrm{~V}_{0.15}\right)\left(\mathrm{Fe}_{7.82} \mathrm{Mn}_{0.114} \mathrm{Si}_{0.06}\right) \mathrm{O}_{32}\right)$ ref. code 01-074-2034), 9\% Calcium magnesium aluminium catena alumo silicate $\left(\mathrm{Ca}\left(\mathrm{Mg}_{0.5} \mathrm{Al}_{0.5}\right)\right.$

$\left(\mathrm{Al}_{0.5} \mathrm{Si}_{1.5} \mathrm{O}_{6}\right)$ ref. code 01-080-0409).

Samples are made in the form of test bricks by using the casting method. The steps of making bricks-test in the study as shown in the diagram Figure 2.

The mass of the stoneware ceramic body is made manually by mixing powdered raw materials according to the composition in Table 1 until a uniform mixture is obtained. While stirring the mixture is given water gradually until a plastically mixture is obtained. The ceramic dough is broiled for 3 days then the mixture is made into 24 test bricks cast with $4 \times 2 \times 1 \mathrm{~cm}^{3}$ mold. The test bricks are left (dried) until the size of the test bricks is relatively unchanged (in this case for 5 days). Furthermore, the test bricks were burned in the furnace at temperatures 
Table 1. The composition of stonewarebody mass.

\begin{tabular}{cccc}
\hline No. & Material & Weight (\%) & Weight (gram) \\
\hline 1 & Nodle clay Kalimantan & 40.0 & 400 \\
2 & Feldspar RRC & 13.5 & 135 \\
3 & Kaolin Belitung & 13.5 & 135 \\
4 & Iron sand from Singaraja & 20.0 & 200 \\
5 & Ball Clay Bantur & 10.0 & 100 \\
6 & Talk & 2.0 & 20 \\
7 & Bentonite & 1.0 & 10 \\
\hline
\end{tabular}

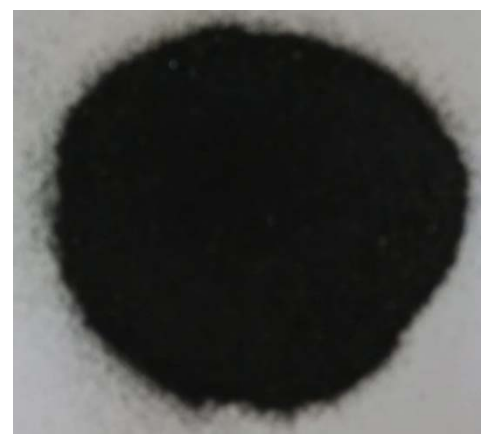

Figure 1. Iron Sand from the coast of Tegal Lenga Singaraja-Bali.

Mixing of the component material as its composition

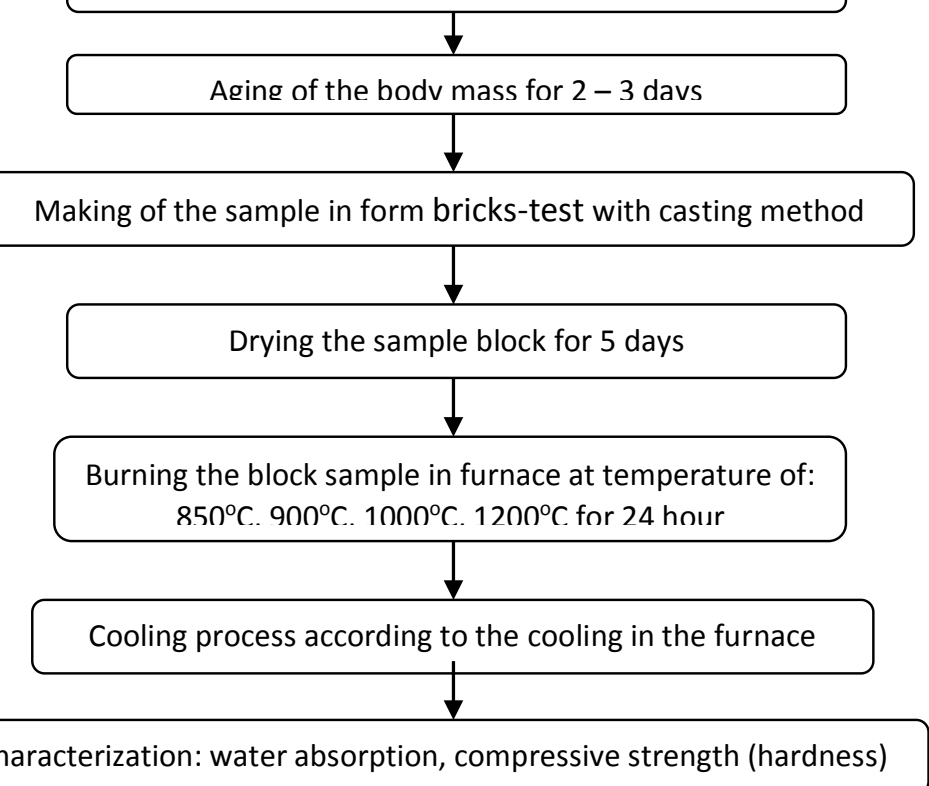

Figure 2. The diagram block of making the sample of stoneware ceramic.

of $850^{\circ} \mathrm{C}, 900^{\circ} \mathrm{C}, 1000^{\circ} \mathrm{C}$ and $1200^{\circ} \mathrm{C}$ each of the 6 test bricks. After 24 hours the sample is cooled according to the cooling inside the furnace. 
The result of the synthesis is stoneware ceramics as shown in Figure 3(a). In comparison, Figure $3(\mathrm{~b})$ is stoneware ceramics with Belitung quartz as a filler where the characteristics of this ceramic have been described in ref. 7 and 8 . From Figure 3(a), it appears that with iron sand obtained stoneware ceramics which are more likely to be brownish gray in color, compared to stoneware ceramics in Figure 3(b) which are more likely to be gray. The brownish gray is possible from the presence of magnetite $\mathrm{Fe}_{3} \mathrm{O}_{4}$ which has a brownish black color on iron sand material.

\subsection{Characterization}

An important parameter of ceramics is the degree of water absorption and its compressive strength (hardness). The level of water absorption is to present how much water is absorbed by the ceramic in units of \%. While the compressive strength represents high of load (force) can be held by ceramics.

Measurement of water absorption is done by immersion method. The test brick before dipping in water is weighed as $k$ in grams. The test bricks water saturated (immersion results) are weighed as $w$ in grams, it the water absorption value be determined by use equation [8] [9],

$$
\text { Water Absorption }=\frac{w-k}{k} \times 100
$$

Material hardness can be represented by its resistance to compressive strength. The compressive strength parameter is determined using the indentation method, In this case, testing the compressive strength was carried out on the test bricks using a compression test machine. The test brick is installed in the middle of the compression testing machine and a very small load is applied to keep the test brick in position. Then the load (force F) is slowly applied to the test brick until so that it breaks to two parts. Then the compressive strength calculated by using the equation [10] [11],

$$
\sigma=\frac{3 F l}{2 b d^{2}}
$$

where $l=$ length, $d=$ thickness, and $b=$ wide of the test brick.

To estimate the effect of combustion on the pores of ceramics produced in this study TGA measurements were carried out. For this purpose, the method of weight loss was used with LECO TGA701 Thermogravimetric Analyzer, the resulting sample was crushed into grains, then left for 15 days to allow the absorption of air (water vapor) by ceramics from the surrounding environment. In grain form TGA characterization is carried out by heating from $27^{\circ} \mathrm{C}-950^{\circ} \mathrm{C}$ at a heating rate of $10^{\circ} \mathrm{C} /$ minutes.

\section{Result and Discussion}

The results of the calculation of water absorption using Equation (1) are given in column 2 of Table 2 . While the results of the calculation of compressive strength parameters using Equation (2) are given in column 3 of Table 2. From Table 2, 


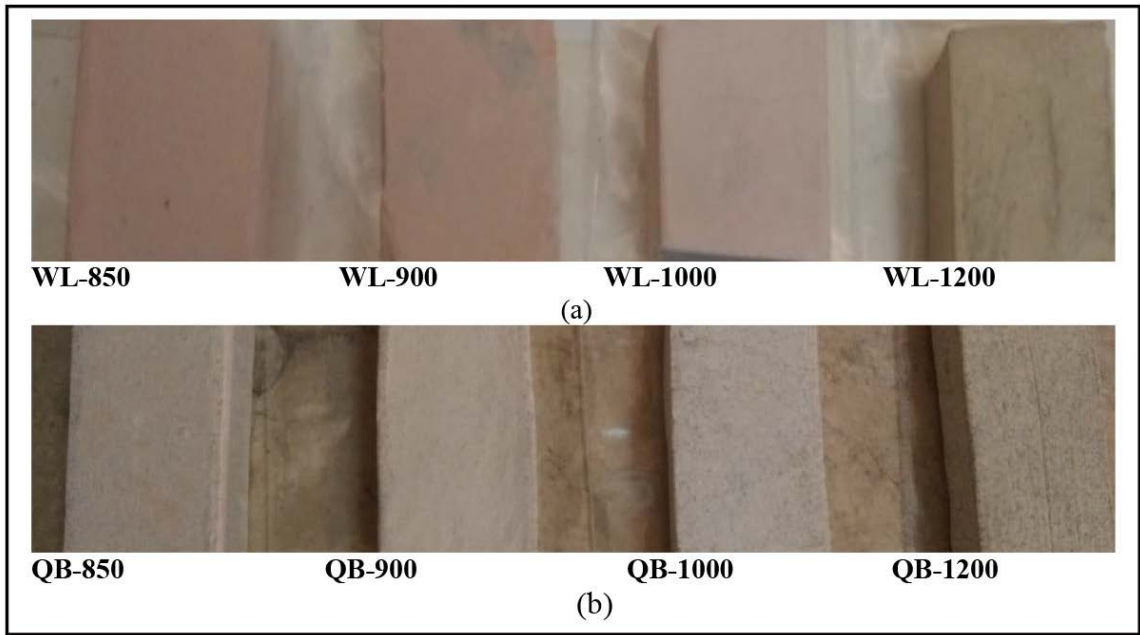

Figure 3. (a) Stoneware ceramics result in this studyby using iron sand as a filling material; (b) Stoneware ceramics by using Belitung quartz as a filling material. WL-850, WL-900, WL-1000, WL-1200 are burning temperature at $850^{\circ} \mathrm{C} 900^{\circ} \mathrm{C}, 1000^{\circ} \mathrm{C}$ and $1200^{\circ} \mathrm{C}$ respectively.

Table 2. Value of water absorption and compressive strength of ceramics with iron sand.

\begin{tabular}{ccc}
\hline Burning Temperature $\left({ }^{\circ} \mathrm{C}\right)$ & Water Absorption (\%) & Compressive Strength $\left(\mathrm{N} / \mathrm{cm}^{2}\right)$ \\
\hline 850 & $15.1 \pm 1.5$ & $11.2 \pm 1.0$ \\
900 & $12.9 \pm 0.2$ & $12.3 \pm 1.3$ \\
1000 & $12.7 \pm 0.3$ & $12.8 \pm 0.8$ \\
1200 & $3.9 \pm 0.1$ & $17.5 \pm 1.7$ \\
\hline
\end{tabular}

it can be observed that there is a decrease in the value of water absorption by increasing the combustion temperature, graphically as shown in Figure 4.

Water absorption parameters (in the immersion method) are closely related to the density of ceramics. The higher the value of the absorption of water, the less dense or porous (hollow) of the ceramics is concerned [8], so that the value of water absorption can be used as an indicator of the initial size of the volume of pores in the ceramic.

From Figure 4, it can be seen that there is a decrease in the absorption value of water with the higher temperature of combustion synthesis. Therefore, there are indications that there is a decrease in porosity (overall volume of pores) by increasing the combustion temperature. It is seen that water absorption tends to decrease linearly with increasing combustion temperature.

The pattern of decreasing water absorption in this study is similar to the results of previous studies which used quartz as a filler material. However, the amount of water absorption in this study was smaller, at combustion temperatures $1200^{\circ} \mathrm{C}$ of $3.9 \%$ was obtained compared with stoneware ceramics with fillers from Belitung quartz, which is $5.5 \%$ [7].

From column 3 in Table 2 it can be observed that the increase in combustion temperature can increase the ceramic compressive strength. Compared with the 


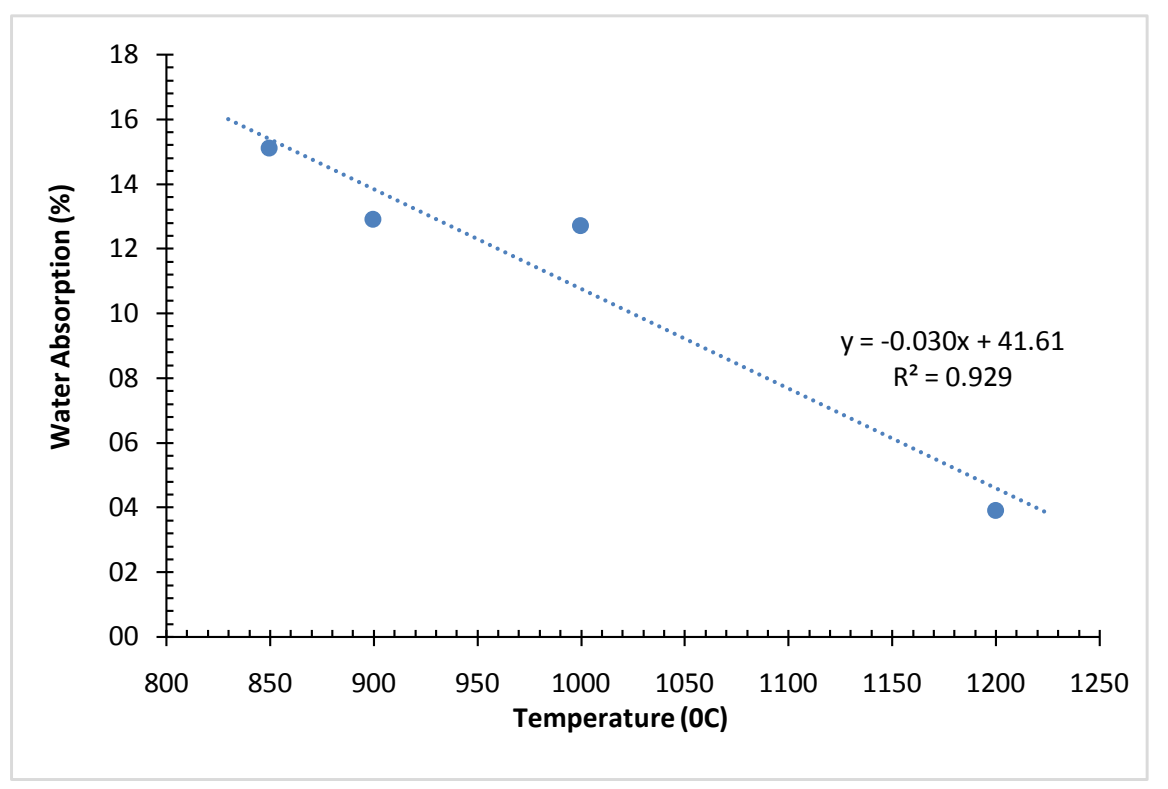

Figure 4. Water absorption versus burning temperature and its linear fitting approach.

results of previous studies on reference 7 the compressive strength is slightly smaller and there is a tendency for differences to increase with increasing combustion temperature. For samples burned at $1200^{\circ} \mathrm{C}$ the difference is $(2.11 \pm$ $0.17) \mathrm{N} \cdot \mathrm{cm}^{-2}$.

The tendency to increase its hardness as a function of combustion temperature graphically as shown in Figure 5. It appears that the pattern of improvement is similar to the results of previous studies [7], it can be fitted by using the least-squares fit a straight line approach with the coefficient of $R^{2}=96 \%$. From the results of measurements of compressive strength and water absorption on the stoneware ceramics resulted in this study, there was an indication occurred of compaction on the structure of the ceramic stoneware with increasing combustion temperature.

Figure 6 and Figure 7 shows the results of TGA characterization of stoneware ceramics produced in this study. Figure 6 shows the rate of weight loss of stoneware ceramics as a function of time, it appears that at minutes of $\sim 10.5$ (at a temperature of $\sim 29^{\circ} \mathrm{C}$ ) the weight loss is negative, heavy additions occur as a result ofair absorption momentarily by ceramics. Then the temperature of the sample rises and the sample loses weight, then at time certain the weight loss is constant. The time at which the weight loss began constants for the sample that was burned at temperature $900^{\circ} \mathrm{C}, 1000^{\circ} \mathrm{C}$ and $1200^{\circ} \mathrm{C}$, successively is at 25.9 , 21.1 and 16.2 minutes.

Figure 7 shows a decrease in weight lossof samples from a temperature of $27^{\circ} \mathrm{C}$ to $900^{\circ} \mathrm{C}$ with the heating rate is $10^{\circ} \mathrm{C} /$ minutes. Initial samples of WL-900, WL-1000, WL-1200 in gram are 1.3515, 1.5064 and 1.4644 respectively. Considering the initial and final height of the curve, and obtained a decrease in sample weight loss of $1.81 \%, 1.29 \%$ and $0.17 \%$ respectively for being burned at $900^{\circ} \mathrm{C}$, $1000^{\circ} \mathrm{C}$ and $1200^{\circ} \mathrm{C}$. 


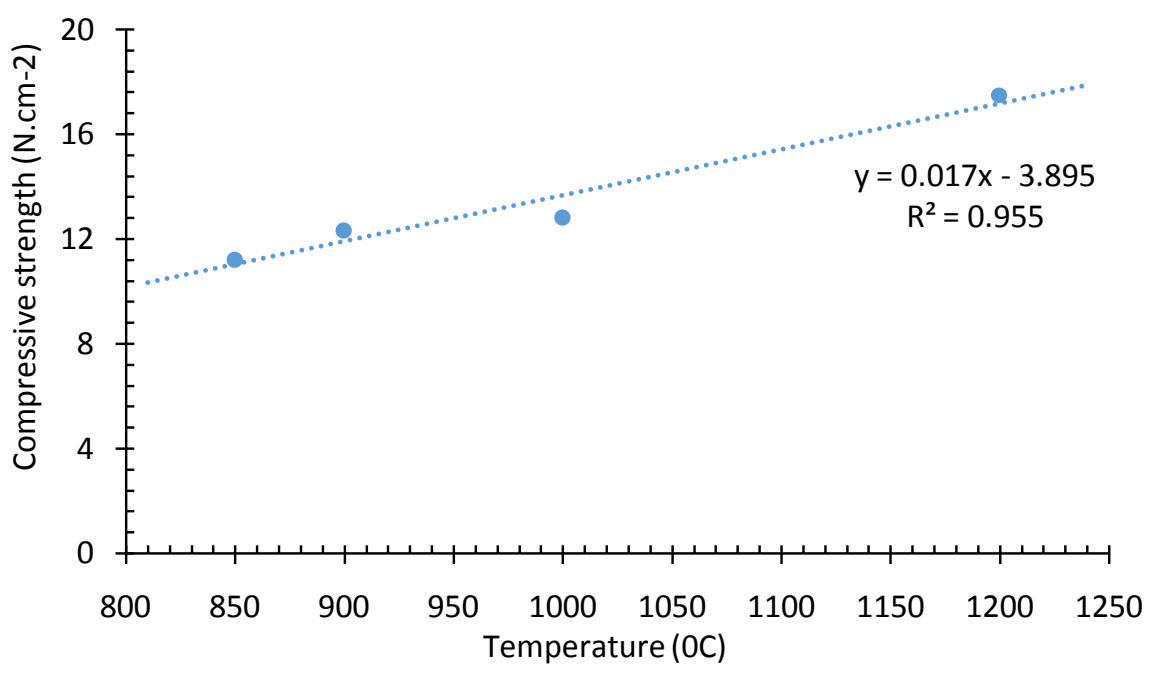

Figure 5. Ceramic hardness vs sintering temperature and its line of linear fitting approach.

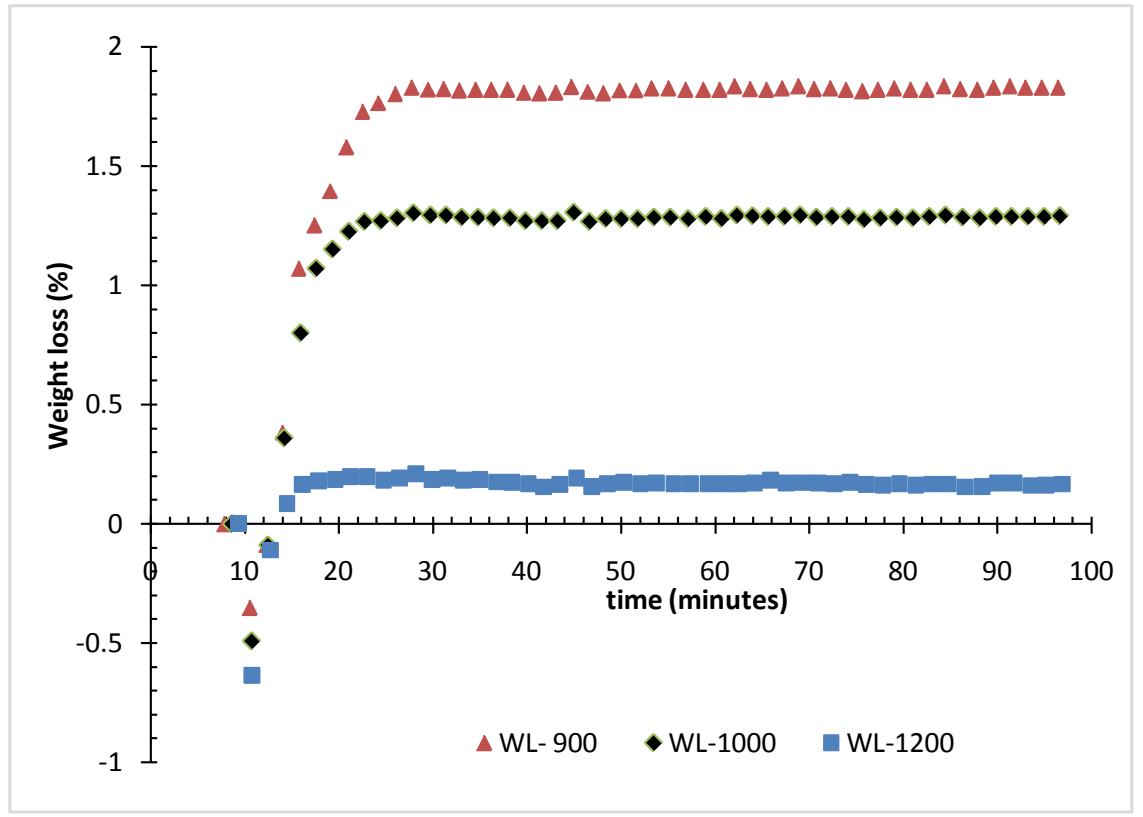

Figure 6. Results of TGA characterization: Percentage of weight lost as a function of time. WL-900, WL-1000, WL- 1200 are burning temperature at $900^{\circ} \mathrm{C}, 1000^{\circ} \mathrm{C}$ and $1200^{\circ} \mathrm{C}$ respectively.

In the TGA characterization, the sample is crushed so that small grains are obtained and left for 15 days so as to allow the absorption of air (water vapor) from the surrounding environment. In ceramic stoneware which has a larger volume of pores it is possible to absorb more air from the surrounding environment. Therefore, the heating in the measurement of TGA results in more air release in ceramics which has a larger volume of pores so that the loss of weight of the ceramic is greater and the time needed to release air from all pores is also longer as shown in Figure 6. From Figure 7, the percentage of smaller weight 


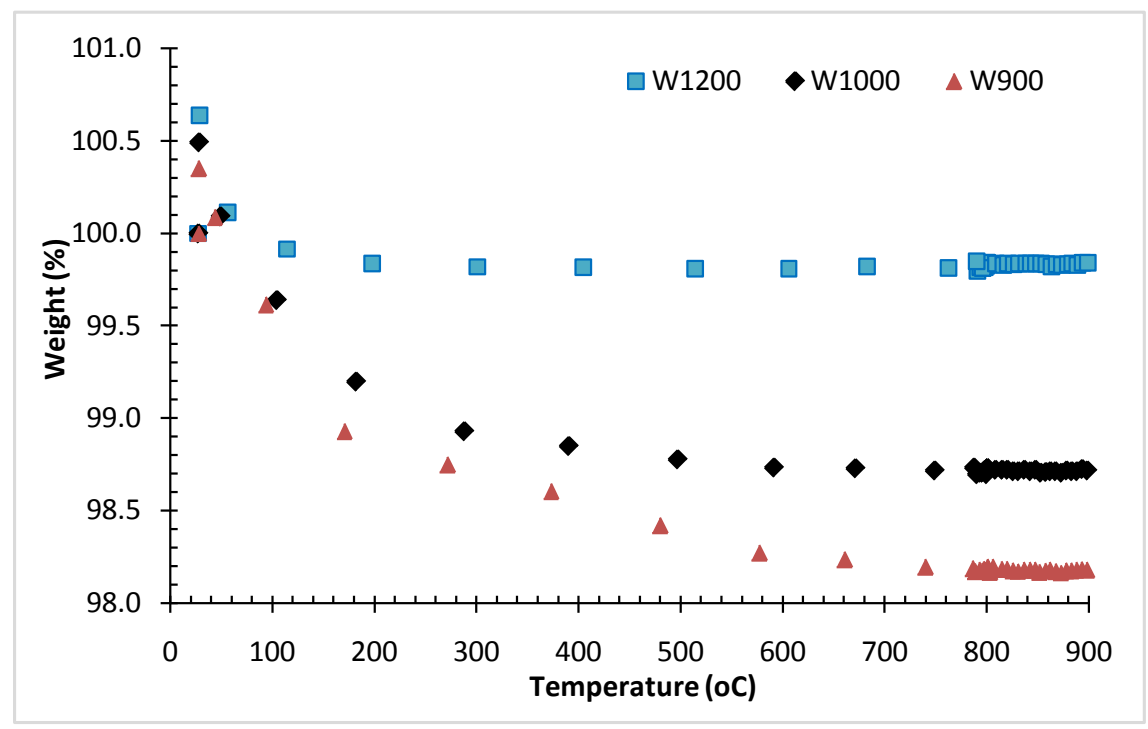

Figure 7. Results of TGA characterization: Weight loss of sample as a function of temperature. WL-900, WL-1000, WL-1200 are burning temperature at $900^{\circ} \mathrm{C}, 1000^{\circ} \mathrm{C}$ and $1200^{\circ} \mathrm{C}$ respectively.

loss occurs in stoneware ceramics produced from the combustion process at higher temperatures. Therefore, there is an indication that the increase in combustion temperature results in a decrease in the porosity of the stoneware ceramic produced, which one is in accordance with the measurement results of water absorption.

The decrease in pore volume in ceramics from higher combustion results can be understood by noting that stoneware ceramics are made from a mixture of binding agents, fillers and smelters. The binder is from clay, (kaolinite) which has a melting point at temperatures around $1740^{\circ} \mathrm{C}$. Fillers are usually used quartz with a melting temperature of around $1715^{\circ} \mathrm{C}$. In this study, as a filler used iron sand which might contain Iron (II, III) oxide, it occurs in nature as the mineral magnetite which has a melting point at a temperature of $1583^{\circ} \mathrm{C}$ $1597^{\circ} \mathrm{C}$. The smelter, i.e. materials containing alkali metals such as feldspar which melt at $1100^{\circ} \mathrm{C}$. With combustion at higher temperatures, it allows more smelting of the smelter. The smelting results fill the pores formed and left behind by mechanical water evaporation and water hydrate [8]. At a temperature of $1000^{\circ} \mathrm{C}$ there is a slight melting of the smelter material, and at temperatures > $1100^{\circ} \mathrm{C}$ more smelting occurs so that more pores are covered, resulting in a decrease in porosity. The decrease in porosity results in an increase in material density so that the compressive strength increases as shown on Figure 5.

In Figure 6 it also appears that at minute of 46.4 there is a small peak at the same temperature for four samples at $\sim 791^{\circ} \mathrm{C}$ as shown in Figure 8. This possibility indicates a chemical reaction that occurs at $\sim 791^{\circ} \mathrm{C}$.

\section{Conclusion}

From the results of this study, information can be obtained that iron sand from 


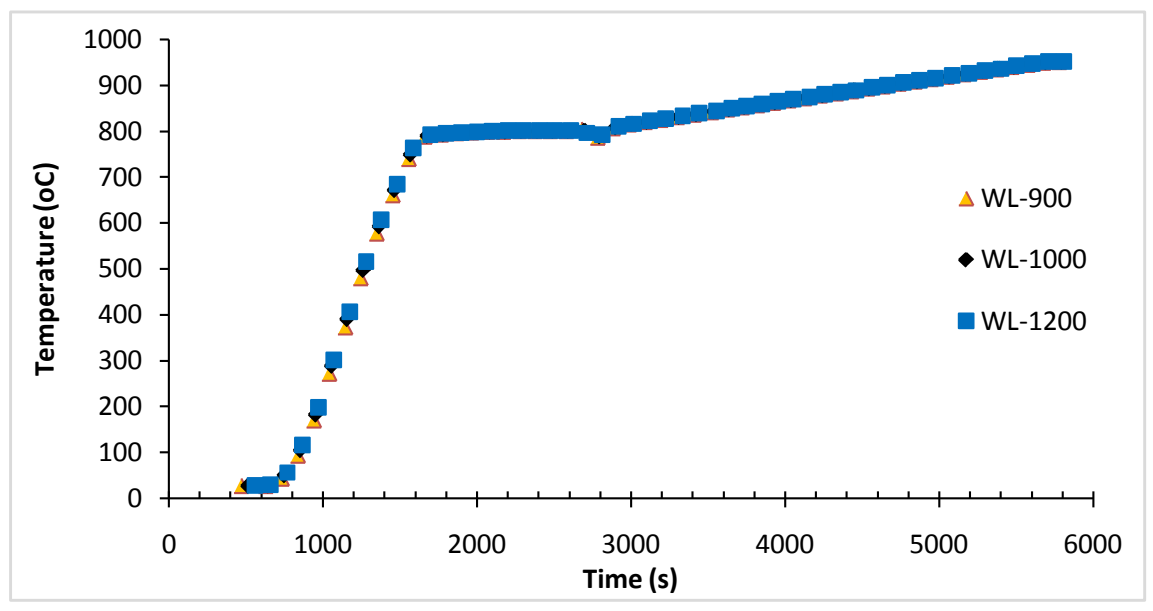

Figure 8. Results of TGA characterization: temperature of samplesas a function of times. WL900, WL1000, WL1200 are burning temperature at $900^{\circ} \mathrm{C}, 1000^{\circ} \mathrm{C}$, and $1200^{\circ} \mathrm{C}$, respectively.

the coast of Tegal Lenga Singaraja can be used as a substitute for Belitung quartz in the synthesis of stoneware ceramics. Stoneware ceramic with water absorption of $(3.9 \pm 0.1) \%$ and compressive strength of $(17.5 \pm 1.7) \mathrm{N} / \mathrm{cm}^{2}$ have been obtained for synthesis at combustion temperature of $1200^{\circ} \mathrm{C}$. The combustion temperature has an impacted on the level water absorption and the compressive strength of the ceramic stoneware, i.e. happened a decrease in the ability of its water absorption and an increase in compressive strength by the increased combustion temperature.

\section{Acknowledgements}

This research was supported by the Featured Grants of Study Program scheme of the Faculty of Mathematics and Natural Sciences, Udayana University. The authors are thankful to LPPM of Udayana University.

\section{Conflicts of Interest}

The authors declare no conflicts of interest regarding the publication of this paper.

\section{References}

[1] Budiyanto, W. (2014) Pengembangan Formula Badan Keramik Stoneware dengan Metode Line Blend, Kriya Keramik PPPPTK Seni Budaya, Sleman Yogyakarta.

[2] Oishi, T. (1986) Ceramics Body, Gifu Prefecture Ceramics Research Institute Nagoya, International Training Center. Japan International Cooperation Agency.

[3] Alexander, B. (2001) Panduan Praktis Kamus Keramik Untuk Praktisi, Perajin dan Industri. Milenia Populer, Australia-Indonesia, Jakarta.

[4] Mason, B. and Moore, C.B. (1982) Principles of Geochemistry. Ellis Horwod Limited, New York.

[5] Lawrence, W.G. and West, R.R. (1982) Ceramics Science for Potter. Chilton Book 
Company, Radnor.

[6] Miller, J.C. (1998) Statistics for Analytical Chemistry. Ellis Horwod Limited, New York.

[7] Sujana, G.A.P.P., Suardana, P. and Nugroho, T. (2019) The Effect of Firing Temperature on Water Absorption and Flexural Strength on the Preparation of Stoneware Ceramic (Coded-BL1P). Buletin Fisika, 20, 25-28.

[8] Sundari, K.N. (2010) Pengaruh Perlakuan Suhu Bakar pada Masa Bodi Keramik Stoneware Kode BL-1 Terhadap Parameter Penyusutan dan Peresapan Air. Majalah Ilmiah Pengkajian Industri, 4, 31-36.

[9] IS 13630 (2006) Indian Standard Ceramic Tiles-Methods of Test, Sampling and Basis for Acceptance: Part 2. Determination of Water Absorption and Bulk Density, Bureau of Indian Standards. Manak Bhavan, New Delhi.

[10] Hadi, S. (2016) Teknologi Bahan, ANDI Yogyakarta.

[11] Chicot, D. and Tricoteaux, A. (2010) Mechanical Properties of Ceramics by Indentation: Principle and Applications in Ceramic Materials. Sciyo, Cap. 7, 116-154. 